Figs. $11 \&$ 12. Different views of a small specimen of the same, in which only two cups are present, of the natural size.

Fig. 13. Portion of the surface of $P$. cuneifornis, enlarged.

Fig. 14. A portion of a thin section of $P$. cuneiformis, magnified, showing lacunos and tubuli.

Fig. 15. Two views of $P$. obtusa, showing the arrangement of the cups; Combe Hill, near Bristol (S. G. Perceval):

Fig. 16. A specimen of P. cyclostoma, viewed from above, showing the mode of fission in one of the cups. Fife.

Fig. 17. Another variety of the same, viewed from above, showing the piling of the cups one upon another. Fife.

Fig. 18. A variety of the same, attached to a Crinoid stem, in which the cells are assuming a more irregular form. Fife.

Fig. 19. Another condition of $\boldsymbol{P}$. cyclostoma (var. Koninckii, nobis), in which the cells are still more elongated and partially free.

Fig. 20. An extreme variety of the same (P. cyclostoma, var. Koninckï, nobis), in which the colony consists of two cells or cups mounted upon a peduncular extension of the base of the colony.

\title{
XXVII.-Descriptions of new Species of Lepidoptera collected by the late Dr. F. Stoliczka during the Indian-Government Mission to Yarkund in 1873. By F. Moore, F.Z.S.
}

\section{Satyrinæ.}

\section{Hipparchia lehana.}

Allied to $H$. baldiva from Upper Kunawur. Upperside paler in colour, the discal transverse luteous band is broader on both wings, and its inner border in the male is inwardly oblique. Both sexes above and beneath are without the small ocellus on the band above the anal angle. The underside is also very much paler, and the transverse sinuous lines wider apart.

Exp. $\delta 2, q 2 \frac{1}{4}$ inches.

Hab. Leh, Kharbu (13,000 feet), Ladak.

\section{Nymphalinæ.}

\section{Vanessa ladakensis.}

Most nearly allied to $V$. rizana from Cheeni. Differing in being somewhat smaller, less angled below the apex of fore wing and at the middle of the hind wing; the black markings on the upperside are much less prominent, the black oblique bands on the fore wing merging into the red, and appearing somewhat confluent; the outer transverse discal yellow band is also broader. Other markings similar. On the underside 
the interspaces between the markings on the fore wing are very much paler.

Exp. $1 \frac{5}{8}$ inch.

Hab. Gogra, Changchenmo (15,000 feet), Ladak; Karatagh lake, on snow $(16,890 \mathrm{ft}$.), Yarkund.

Pierinæ.

BaL'Ta, n. g.

Fore wing very short, costa considerably arched from the base, apex and posterior angle rounded, exterior margin oblique; costal vein short; subcostal vein arched to end of the cell, five-branched, first and second branches arising at equal distance apart before the end of the cell and terminating on the costa before the apex; third branch bent near its base but beyond the discocellulars, at its middle, and immediately before its termination before the apex; the fourth and fifth branches, and the radial branch starting respectively below from each of these angles, the fourth branch being very short, and in the female the radial starts from end of the cell; cell broad ; discocellulars of nearly equal length, oblique, slightly bent inward; median vein three-branched, at equal distances; submedian curved: hind wing long, somewhat oval, slightly broader than fore wing; apex and exterior margin very convex, abdominal margin long; costal vein short; subcostal threebranched; cell broad; discocellulars oblique, upper shortest; median three-branched; submedian nearly straight. Body small; abdomen short; thorax and front of head clothed with long lax hairs. Palpi very long, slender, densely hairy beneath. Legs short, femora fringed beneath with long lax hairs; antennæ short, club large and spatulate.

Allied to Mesapia (M. peloria, Hewits. Exot. Butt. i. Pierida, pl. 2. f. 15).

\section{Baltia Shawii.}

Mesapia Shawii, Bates, in Henderson's 'Lahore to Yarkund, p. 305 (1873), 오.

Male. Upperside white ; base of both wings densely blackspeckled; fore wing with the costal edge ochreous and slightly black-speckled; a large black triangnlar oblique spot at end of the cell; a short transverse subapical black band, and a marginal row of black decreasing triangular spots : hind wing sparsely and minutely speckled with dark grey, the speckles dense across the disk, and there forming a curved sinuons indistinct band, a slight black streak at end of the cell. Body black. Palpi ochreous above, fringed with black beneath. 
Antennæ black, stem white-ringed. Abdomen beneath yellow. Legs black above, white beneath. Underside-fore wing with markings as above; costa and exterior margin tinged with ochreous: hind wing black-speckled, densely at base, and also forming a narrow curved discal sinuous band; a slight black streak at end of the cell.

Female differs in having the markings above less black, the subapical band on the fore wing being continued across the wing on both upper and underside.

Exp. $1 \frac{5}{10}$ inch.

$H a b$. Aktagh (15,590 feet), Yarkund (Stoliczka); ChangLung Pass, 18,000 feet (Shaw).

\section{Colias Stoliczkana.}

Male. Upperside pale chrome-yellow, base of costal and abdominal borders greenish yellow; base of wings speckled with blackish brown; both wings with a broad yellowish. brown marginal band; a slight narrow dusky lunular streak at end of the cell in the fore wing. Underside-fore wing pale yellow, costal border and exterior margin greenish yellow; a dusky black-speckled lunular spot at end of the cell, and a discal row of indistinct speckled spots : hind wing greenish yellow, with darker green speckles; an ochreous-brown patch at end of the cell enclosing a white irregular mark and dot; a discal series of dusky-brown dentate spots. Antenne and legs reddish.

Exp. $1 \frac{1}{2}$ inch.

$H a b$. North of Changla (17,000 feet), Ladak.

Nearest to C. eogene, Felder, Nov. Reise, Lep. pl. 27. f. 7. Differs in being smaller, and having the median portion and cilia pale chrome-yellow (instead of orange), the discocellular mark of fore wing less prominent and lumular (instead of oval); the broad marginal band is yellow-brown (instead of dark brown), the costa and head being also of the same yellow as the other part. On the underside the discocellular mark is also lunular and not pale-centred.

\section{Lycæninæ.}

Polyommatus yarkundensis.

Allied to $P$. icarus.

Upperside dark blue, anterior and exterior borders dusky brown ; fore wing with an indistinct streak at end of the cell; hind wing with a marginal row of rather indistinct ochreousbordered black spots. Cilia cinereous white. Underside ochreous grey : fore wing with a white-centred black spot in 
middle of the cell, another below it, one at end of the cell, and a curved discal series of seven spots; a marginal row of indistinct spots bordered above by a dentate line with pale ochreous interspaces: hind wing with three white-circled black subbasal spots and a curved discal series of seven spots; a marginal row of prominent spots bordered above by dentate line with ochreous interspaces.

Exp. $1 \frac{2}{8}$ inch.

Hab. Yarkund (3923 feet).

Polyommatus kashgharensis.

Allied to P. semiargus.

Male. Upperside pale blue, with narrow black exterior marginal line; costal edge white; cilia white, with dark inner border. Underside slightly pearly grey; base of the wings pale metallic green : fore wing with a whitish-bordered black spot in middle of the cell, and a curved discal series of five spots; a very indistinct spot at end of the cell, and a less distinct marginal series of spots: hind wing with three subbasal and a curved discal series of six small white-circled black spots, an indistinct spot at end of the cell, and a marginal row of spots with slightly ochreous upper dentate line.

Exp. 12 inch.

Hab. Yangihissar (4320 feet), Yarkund.

\section{Polyommatus lehanus.}

Allied to $P$. pheretes.

Male. Upperside violet-blue, somewhat brownish blue at the margins; cilia white. Underside leaden grey, palest at the apex and on hind wing; fore wing with a white-bordered black spot at end of the cell, and a transverse discal oblique series of five spots : hind wing with a large triangular greyishwhite spot at end of the cell, and a series of eight small round spots recurving from near base of costa across the disk to anal angle.

Exp. $\frac{9}{10}$ inch.

Hab. Leh (11,538 feet), Ladak.

\section{Bombycidø.}

Arctia orientalis.

Similar to $A$. caja, differing above on the fore wing in the general form of the bands, these being entire and transversely continuous (not broken longitudinally as in caja) ; on the hind wing the spot at the end of the cell is absent; this wing also has a yellowish-white narrow marginal line above, and brown 
cilia both above and beneath; the dorsal black band is present on each segment, and longer.

Exp. $2 \frac{1}{2}$ inches.

Hab. Sonamurg, Cashmere (Stoliczka).

\section{Euproctis kargatika.}

Male and female. Fore wing creamy white, veins greyish white; a large brown-speckled ochreous discocellular spot and a row of submarginal spots: hind wing white. Thorax creamy white; abdomen of male golden yellow, of female grey with slight black rings and large glossy golden-yellow tuft. Shaft of antennæ white, pectinations brown. Underside glossy white; costa of fore wing in male broadly suffused with brown.

Exp. o $1 \frac{5}{10}$, o $1 \frac{8}{10}$ inch.

Hab. Kargalik (4440 feet), Yarkund.

\section{Euproctis lactea.}

Uniform cream-white, without markings. Abdominal tuft pale yellow. Underside paler cream-white, costal border of fore wing ochreous brown. Palpi ochreous brown. Antennæ pale ochreous brown, shaft white. Fore tibiæ with ochreous-brown tuft.

Exp. 12 inch.

$H a b$. Kargalik (4440 feet), Yarkund.

\section{Oxicesta marmorea.}

Male. Upperside greyish brown: fore wing with a pale yellowish irregular streak along middle of the cell to costa near the apex, a small spot beyond the cell, and an indistinct pale streak below the cell ; apical margin of costa and outer margin pale testaceous, alternated with a short black streak which extends through the cilia: hind wing uniform pale greyish brown, slightly yellowish at the base. Body and legs greyish brown. Antennæ brown. Underside uniform greyish brown. Cilia of fore wing with black streak.

Exp. $1 \frac{1}{10}$ inch.

Hab. Sasstekke, Yarkund.

Differs from $O$. geographica in being longer in the wings, of different colour, and without the two transverse zigzag white bands on the fore wing.

\section{Ptilophora kashghara.}

Male. Pale grey; fore wing irrorated with brown scales, crossed by three indistinctly defined narrow zigzag brown 
bands, which ares lightly dentate on the veins; cilia alternate pale grey and brown: hind wing pale grey, sparsely sprinkled with brown scales. Thorax greyish brown. Abdomen brown, three anterior segments with dorsal row of black tubercular scales, tip also black. Antennæ yellowish testaceous. Underside grey, sparsely brown-speckled, long pubescence of abdominal border brown and black. Legs pale brown.

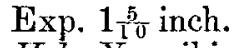

$H a b$. Yangihissar (4320 feet), Kashghar.

\section{Noctuidà.}

Acronycta kargalika.

Female. Fore wing pale silvery brownish grey; reniform and orbicular marks whitish, contiguous, brown-bordered; a longitudinal streak from the base, a contiguous subbasal transverse recurved line, a discal transverse lunular line crossed near posterior angle by a short streak; some short costal marks and a streak on cilia between each vein brown: hind wing glossy greyish white, outer borders and veins pale greyish brown. Thorax and abdomen dark grey. Antennæ grey. Underside greyish white: fore wing with greyish-brown costal streaks and hind margin; hind wing with brown basal costal streak and discocellular spot. Palpi brown at sides. Legs grey, femora tipped with black; tibiæ longitudinally streaked and tarsi banded with black.

Exp. $1 \frac{5}{10}$ inch.

Hab. Kargalik (4440 feet), Yarkund.

Most nearly allied to $A$. tridens, but differs in being darker; the markings are somewhat similar; but the basal longitudinal streak is shorter, thus giving a wider interspace between the two transverse lines.

\section{Hydracia tibetana.}

Male. Pale reddish testaceous; fore wing crossed by two pale brown narrow lines with pale inner border, the first line subbasal and outwardly oblique, the other discal; a submarginal row of blackish dots, and pale marginal line; orbicular and reniform spots indistinct, but defined by a brownish border: hind wing and abdomen paler. Underside palest on the middle of the wings; discal line on both wings, and a discocellular spot slightly perceptible on the hind wing. Antennæ, palpi, and fore legs reddish testaceous.

Exp. $1 \frac{5}{10}$ inch.

Hab. Leh, Ladak. 


\section{Mamestra canescens.}

Male. Fore wing brownish grey; orbicular and reniform marks greyish white, with narrow black border; a short double black streak below the base of the cell, and a quadrate mark below the orbicular spot; an indistinct pale submarginal irregular fascia, and black marginal lunular line with whitish inner border: hind wing pale greyish brown. Thorax and abdomen greyish brown; antennæ brown. Underside glossy pale greyish brown, both wings with indistinct short transverse discocellular streak.

Exp. $1 \frac{5}{8}$ inch.

Hab. Kargalik (4440 feet), Yarkund.

\section{Agrotis tibetana.}

Upperside-fore wing greyish brown, with indistinct dusky transverse subbasal double sinuous line, discal dentate lines, and pale outer-bordered, wavy, narrow, submarginal band; speckled orbicular and quadrate reniform mark; cilia with narrow white marginal line: hind wing brownish white; veins and outer margin brown; cilia white. Antennæ and body greyish brown, tip of abdomen yellowish. Undersidefore wing greyish white, dusky brown basally along the costa and hind margin, and speckled on outer margin: hind wing whitish; an indistinct dusky spot at end of the cell, a spot mesially on each vein, and narrow lunular marginal line. Legs greyish brown, femora and tibiæ streaked and tarsi banded with black.

Allied to A. ripce.

Exp. 13 inch.

Hab. Leh, Ladak.

\section{Spalotis undulans.}

Male and female. Fore wing grey-brown, irrorated with darker scales; crossed with subbasal, antemedian and postmedian double pale-bordered lunular brown bands, each ending on the costa in a darker spot; a submarginal pale outerbordered brown wavy fascia, and small black marginal lunules: hind wing glossy greyish white, with brownish tinged borders, brown veins, and marginal lunular line. Antennæ and palpi greyish brown. Underside glossy greyish white; tibiæ streaked and tarsi banded with black.

Allied to S. pyrophila.

Exp. $1 \frac{8}{10}$ inch.

Hab. Ak Masjid, S.E. of Chiklik, Yarkund. Ann. \& Mag. N. Hist. Ser. 5. Vol. i. 


\section{Toniocampa chiklika.}

Male. Upperside grey : fore wing densely brown-speckled; cilia with a brown-speckled line; orbicular and reniform spots pale; an indistinct transverse subbasal and discal simuous pale-bordered line: hind wing minutely brown-speckled, and with a pale brown cilial line. Underside paler, both wings uniformly speckled, and with a very indistinct sinuous discal band. Antennæ blackish, shaft grey. Body, palpi, and legs brown-speckled.

Exp. $1 \frac{5}{8}$ inch.

Hab. S.E. of Chiklik, Yarkund.

\section{Hadena Stoliczkana.}

Male. Fore wing pale greyish brown, crossed by three indistinct, narrow, brownish, zigzag double lines; orbicular spot pale ; reniform mark very indistinct; two black spots linearly disposed below the apex ; a double, narrow, marginal, blackish lunular line; some short streaks on the costa : hind wing with the veins and a broad marginal band fuliginous brown. Cilia white. Body pale greyish brown. Antennæ brown. Underside greyish white; both wings crossed by a distinct brown curved discal band; fore wing with a discocellular brown lunule, and hind wing with a spot; a marginal lunular dotted line. Legs grey-brown, banded with black.

Exp. $1 \frac{4}{8}$ inch.

Hab. Kufelang (14,810 feet), Yarkund.

\section{Heliothis hybloooïdes.}

Upperside-fore wing grey, minutely brown-speckled; a slightly apparent brown streak at end of the cell, and a pale submarginal zigzag line : hind wing brownish white, with a broad greyish-black median transverse band, which is confluent with a curved discocellular black streak; a large oval black spot on middle of outer margin, abdominal border fringed with brown. Cilia white. Body grey, whitish beneath. Legs greyish white and brown-speckled. Underside greyish white: fore wing with a dusky black, broad, transverse apical band, and an outwardly oblique median band: hind wing with a dusky black dentate streak at end of the cell ; a slight median band and oval marginal spot.

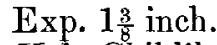

$H a b$. Chiklik. $(14,480$ feet), Yarkund. 


\section{Pyralidæ.}

\section{Pyrausta cuprealis.}

Upperside dark cupreous brown: hind wing with a broad median discal yellow band. Underside paler, basal two thirds of both wings yellow, with brown-speckled subbasal patch. Antennæ black. Body beneath cupreous black, speckled with yellow. Palpi yellow beneath. Legs yellow, with cupreous speckles.

Exp. $\frac{5}{8}$ inch.

$H_{a} \bar{b}$. Gaganghir (near Sonamurg), Cashmere.

\section{Eudorea granitalis.}

Upperside-fore wing pale brown, crossed by several irregular wavy grey-bordered black lines; cilia grey alternated with black: hind wing greyish white, traversed by numerous short, brown striæ, somewhat regularly disposed between the veins, the wing being suffused with brown along external margin. Cilia grey, with dusky line. Body grey, speckled with brown. Palpi brown at apex, greyish at base. Legs grey, speckled with black. Underside as above, markings paler.

Exp. $\frac{8}{10}$ inch.

Hab. S.E. of Chiklik, Yarkund.

\section{Eudorea transversalis.}

Male. Upperside-fore wing grey, speckled with brown ; crossed by an oblique subbasal and a recurved discal blackspeckled band; exterior margin black-spotted; some black speckles at end of the cell : hind wing pale brown, with darker marginal border. Cilia grey, with brown border. Body grey-brown and black-speckled. Palpi speckled with black and white above. Antennæ dark brown. Underside pale ochreous grey. Legs speckled grey and black, fore and middle legs with grey bands.

Femate paler, the bands across fore wing somewhat broader, those on the hind wing more distinct.

Exp. $\frac{6}{10}$ inch.

Hab. Ighizyar (5600 feet), Yangihissar (4320 feet), Yarkund.

\section{Geometridæ.}

\section{Gnophos Stoliczkaria.}

Upperside pale ochreous grey, minutely brown-speckled, forming more or less numerous short transverse strix; both wings with an indistinct oval spot at end of the cell; fore wing with a subbasal and discal, and hind wing with a discal series 
of dentate points, and marginal lunular dotted line. Cilia white. Underside paler; speckles sparsely apparent; cell-spot less distinct.

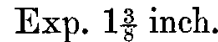

Hab. Ak Masjid (8870 feet), Yarkund.

\section{Thera kashghara.}

Upperside pale brownish cinereous : fore wing crossed by three equidistant pale-bordered blackish lines, the basal nearly straight, the second slightly waved, the outer irregularly undulated, each darkest at the costal end ; the interspaces between the two outer lines darker cinereous brown; a slight short sinuous spot at apex, an indistinct paler transverse undulating line on outer margin, and a distinct darker narrow marginal line. Underside paler, transverse lines very indistinctly visible. Legs dusky above. Antennæ brownish.

Exp. 13 inch.

Hab. Chiklik (14,480 feet), Yarkund.

\section{Crambidæ.}

Homoesoma venosella.

Upperside-fore wing pale greyish ochreous, minutely brown-speckled, sparsely disposed along the veins, and having a transverse pale discal indented line and an indistinct space at end of the cell; hind wing cinereous white, with pale brown marginal line. Cilia white. Body and palpi above greyish ochreous, paler beneath. Underside whitish cinereous.

Exp. $\frac{7}{8}$ inch.

Hab. Ak Masjid (8870 feet), Yarkund.

\section{Myelois griseella.}

Upperside cinereous grey; fore wing densely irrorated with brown, crossed by two median, undulating, very indistinct speckled lines; an indistinct streak at end of the cell; both wings with an outer marginal narrow Iunular brown line: hind wing whitish, with a very pale cinereous-brown marginal and an indistinct narrow submarginal band. Cilia whitish, with a narrow darker marginal line. Underside paler cinereous. Head and thorax brownish. Abdomen cinereous brown.

Exp. $1 \frac{1}{8}$ inch.

Hab. S.E. of Chiklik, Yarkund.

Myelois undulosella.

Male and female. Upperside ochreous grey; fore wing 
speckled with brown, crossed by two pale-bordered, median, oblique, undulating, blackish lines, both of which are sinuous at the costal end, and enclosing a dark pale-centred streak at end of the cell; middle of hind margin and the outer border grey, the latter with an indistinct pale sinuous line slightly black-speckled; cilia whitish, alternated with two dark marginal lines: hind wing pale brownish cinereous externally; cilia white, alternated with one dark marginal line, and a dark patch at the middle. Body ochreous grey. Underside pale cinereous.

Exp. $1 \frac{2}{8}$ inch.

Hab. Ak Masjid (8870 feet), Ak Talla (7342 feet), Yarkund.

Tortricidæ.

Conchylis Stoliczkana.

Upperside-fore wing white, with three transverse, outwardly oblique, ochreous-brown bands, two inwardly oblique discal bands, and a spot at end of the cell; a brown-speckled marginal band: hind wing cinereous white, with narrow brown marginal band. Body white, speckled with black, and with white segmental bands. Legs white. Palpi white, speckled with brown. Underside cinereous white; outer bands on fore wing indistinctly visible.

Exp. $\frac{6}{8}$ inch.

Hab. S.E. of Chiklik, Yarkund.

\section{Tineidæ.}

Depressaria stigmella.

Fore wing pale brownish ochreous, greyish along the apical portion of the costa, interspersed with a few dusky speckles; a dusky grey short straight streak at end of the cell; a few speckles on outer margin: hind wing pale ochreous white. Underside paler. Legs pale ochreous.

Exp. $\frac{9}{10}$ inch.

Hab. Yangihissar (4320 feet), Kashgar.

Nearest allied to the European D. subpropinquella.

XXVIII.-Description of a new Species of Land-Planarian from the Hothouses at Kew Gardens. By H. N. Moseley, F.R.S.

From time to time interesting worms and other invertebrates are found living in the various hothouses at Kew Gardens. 